\title{
Evidence for facial nerve palsy and SARS-CoV-2
}

\author{
Evidências para paralisia do nervo facial e SARS-CoV-2
}

\section{Evidencia de parálisis del nervio facial y SARS-CoV-2}

\author{
Samuel Gomes da Silva Teles ${ }^{1}$, André Luís Santos Carneiro², \\ Rita de Cássia Siqueira Pestana ${ }^{3}$
}

\begin{abstract}
1.Laboratory of Morphology and Human Anatomy, Department of Dentistry, Centro Universitário Fluminense (UNIFLU), Campos dos Goytacazes-RJ, Brazil.

2.Captain Surgeon-Dentist of the Military Fire Department of the State of Rio de Janeiro CBMRJ and Implantodontist, Department of Dentistry, Centro Universitário Fluminense (UNIFLU). Campos dos Goytacazes-RJ, Brazil.

3.Dental Surgeon Master in Biosciences and Biotechnology by UENF, Laboratory of Morphology and Human Anatomy, Department of Dentistry, Centro Universitário Fluminense (UNIFLU). Campos dos GoytacazesRJ, Brazil.
\end{abstract}

\begin{abstract}
Resumo
Introdução. A Organização Mundial da Saúde (OMS) reconheceu uma nova cepa de coronavírus, a Síndrome Respiratória Aguda Grave Coronavírus 2 (SARS-CoV-2), chamada Doença Coronavírus 2019 (COVID-19). Os sintomas mais leves e comuns incluem febre, fadiga e tosse; no entanto, casos mais graves da doença podem causar dificuldades respiratórias, insuficiência renal e cardíaca e, eventualmente, morte. No entanto, um número crescente de relatos de manifestações neurológicas tem surgido. Objetivo. Proporcionar uma revisão abrangente das manifestações neurológicas da SARS-CoV-2 e principalmente a relação entre a paralisia aguda do nervo facial e a COVID-19 bem como seus resultados na mortalidade e as implicações que isso tem na prática clínica. Método. A pesquisa em sete bancos de dados (PubMed, Cochrane Library, Lilacs, Scielo, Web of Science, Scopus e Google Scholar) foi realizada por dois revisores independentes na busca por evidências da paralisia do Nervo Facial (VII) e SARS-CoV-2. Após a triagem os dados foram coletados e discutidos. Resultados. A paralisia facial idiopática é chamada de paralisia de Bell e estudos mostraram que a paralisia facial aumentou durante o período de pandemia de COVID-19. Existem muitos relatos sobre a relação entre COVID-19 e paralisia facial, porém pouca evidência real de sua relação. Conclusão. Ainda é questionável se esses distúrbios neuroimunológicos ocorrem diretamente da infecção viral ou como sequelas autoimunes. A patogênese da doença por trás dessa manifestação ainda não é totalmente compreendida. Acreditamos que mais pesquisas devam ser realizadas para esclarecer a associação levantada por este estudo.
\end{abstract}

Unitermos. COVID-19; paralisia facial; nervos; SARS-CoV-2

\footnotetext{
Abstract

Introduction. The World Health Organization (WHO) has recognized a new strain of coronavirus, the Severe Acute Respiratory Syndrome Coronavirus 2 (SARS-CoV-2), called Coronavirus Disease 2019 (COVID-19). The mildest and most common symptoms include fever, fatigue and cough; however, more severe cases of the disease can cause breathing difficulties, kidney and heart failure and, eventually, death. However, an increasing number of reports of neurological manifestations have emerged. Objective. Provide a comprehensive review of the neurological manifestations of SARS-CoV-2 and especially the relationship between acute facial nerve palsy and COVID-19, as well as their results in mortality and the implications that this has in clinical practice. Method. The search in seven databases (PubMed, Cochrane Library, Lilacs, Scielo, Web of Science, Scopus and Google Scholar) was carried out by two independent reviewers in search of evidence of Facial Nerve Palsy (VII) and SARS-CoV2 . After screening, data were collected and discussed. Results. Idiopathic facial palsy is called Bell's palsy and studies have shown that facial palsy increased during the COVID-19 pandemic period. There are many reports on the relationship between COVID-19 and facial paralysis, but little real evidence of their relationship. Conclusion. It is still questionable whether these
} 
neuroimmune disorders occur directly from viral infection or as autoimmune sequelae. The pathogenesis of the disease behind this manifestation is not yet fully understood. We believe that more research should be carried out to clarify the association raised by this study.

Keywords. COVID-19; facial paralysis; nerves; SARS-CoV-2

\section{Resumen}

Introducción. La Organización Mundial de la Salud (OMS) ha reconocido una nueva cepa de coronavirus, el Síndrome Respiratorio Agudo Severo Coronavirus 2 (SARS-CoV-2), Ilamado Enfermedad por Coronavirus 2019 (COVID-19). Los síntomas más leves y comunes incluyen fiebre, fatiga y tos; sin embargo, los casos más graves de la enfermedad pueden causar dificultades respiratorias, insuficiencia renal y cardíaca y, finalmente, la muerte. Sin embargo, ha surgido un número creciente de informes de manifestaciones neurológicas. Objetivo. Brindar una revisión integral de las manifestaciones neurológicas del SARS-CoV-2 y especialmente la relación entre la parálisis aguda del nervio facial y el COVID-19, así como sus resultados en la mortalidad y las implicaciones que esto tiene en la práctica clínica. Método. La búsqueda en siete bases de datos (PubMed, Cochrane Library, Lilacs, Scielo, Web of Science, Scopus y Google Scholar) fue realizada por dos revisores independientes en busca de evidencia de Facial Nerve Palsy (VII) y SARS-CoV-2. Después de la selección, los datos se recopilaron y discutieron. Resultados. La parálisis facial idiopática se llama parálisis de Bell y los estudios han demostrado que la parálisis facial aumentó durante el período pandémico de COVID-19. Hay muchos informes sobre la relación entre COVID-19 y la parálisis facial, pero poca evidencia real de su relación. Conclusión. Todavía es cuestionable si estos trastornos neuroinmunitarios se producen directamente a partir de una infección viral o como secuelas autoinmunes. La patogenia de la enfermedad detrás de esta manifestación aún no se comprende completamente. Creemos que se deben realizar más investigaciones para esclarecer la asociación que suscita este estudio.

Palabras clave. COVID-19; parálisis facial; nervios; SARS-CoV-2

Research developed in Centro Universitário Fluminense (UNIFLU). Campos dos Goytacazes-RJ, Brazil.

Corresponding author: Samuel GS Teles. Av. Visconde de Alvarenga 143. Pq. Leopoldina. Campos dos Goytacazes-RJ, Brazil. CEP 28053-000. Email: samuel.gomes100@hotmail.com

\section{INTRODUCTION}

In an outbreak that broke out in Wuhan in December 2019, the World Health Organization (WHO) recognized a new strain of coronavirus, the Severe Acute Respiratory Syndrome Coronavirus 2 (SARS-CoV-2), called Coronavirus Disease 2019 (COVID-19). The cases started to be widely detected in February 2020. This new virus therefore caused a global pandemic and was also widely reported due to a series of respiratory manifestations. The mildest and most common symptoms include fever, fatigue and cough; however, more severe cases of the disease can cause 
breathing difficulties, kidney and heart failure and, eventually, death ${ }^{1}$. However, an increasing number of reports of neurological manifestations have emerged ${ }^{2}$.

The aim of this study is to provide a comprehensive review of the neurological manifestations of SARS-CoV-2 and especially the relationship between acute facial nerve palsy and COVID-19, as well as their results in mortality and the implications that this has in clinical practice.

\section{METHOD}

The search in seven databases (PubMed, Cochrane Library, Lilacs, Scielo, Web of Science, Scopus and Google Scholar) was performed in search of evidence of Facial Nerve palsy (VII) and SARS-CoV-2. When considering the eligibility criteria, the inclusion criteria were: 1) publications that report neurological manifestations of SARS-CoV-2 and mainly the relationship between COVID-19 and acute facial nerve palsy. 2) present the terms COVID-19 OR SARS-CoV2 OR 2019-nCoV) AND "Facial nerve" and its variations. 3) publications in all languages available in the databases researched. The following exclusion criteria were considered: 1) publications where the terms COVID-19 and its variations and Facial Nerve appear only in the authors' affiliation or in the references. 2) publications that do not directly discuss the central objective of the topic.

The titles of all stored publications were read, and, when necessary, the summary, introduction and/or results and discussion sections were carefully investigated to ensure 
that the publications met the eligibility criteria. After screening, data were collected and discussed.

41 publications were selected to prepare the synthesis of this article after applying the selection method. Duplicates between databases $(n=32)$ were initially excluded, and the electronic search procedure retrieved 5820 publications. After reading the titles and abstracts, 5388 publications were excluded (they did not directly discuss the evidence between facial paralysis and SARS-CoV-2: $n=4322$; the terms COVID19, Facial Paralysis and SARS-CoV-2 were only included in the affiliation of authors or references in the publication: $\mathrm{n}=1066$ ) and 400 texts were conducted for full reading.

From the selected publications, the following were found: $28(68.4 \%)$ original articles, $8(19.6 \%)$ review articles, $2(4.8 \%)$ Letters to editors, 1 (2.4\%) Short communications, 1 (2.4\%) Letter and 1 (2.4\%) Comment. Authors from 14 countries representing five continents were found. Among the publications, 31 (75.6\%) directly discussed the evidence between facial paralysis and SARSCoV-2. Other $6(14.7 \%)$ publications only demonstrated etiological aspects and clinical manifestations of facial paralysis and only $4(9.7 \%)$ reported diagnostic aspects of COVID-19.

\section{RESULTS AND DISCUSSION}

Experimental studies using transgenic mice suggest that SARS-COV and MERS-COV may enter the central nervous system intranasally through the olfactory nerve. 
Once in the brain, they have the potential to spread to the thalamus and brain stem, two regions highly involved in coronaviridae infections ${ }^{3-5}$. It has been suggested that SARSCoV-2 can enter the central nervous system in two ways: first through systemic vascular dissemination and, second, more locally through the cribiform lamina of the ethmoid bone, which may or may not affect the association with anosmia often described by patients with SARS-CoV-2. Upon entering the systemic circulation, the virus will invade the nervous tissue due to its neurotropism properties. Here, it binds and interacts with angiotensin-converting enzyme 2 (ACE2) receptors in the capillary endothelium ${ }^{6}$.

Studies on the structural integrity of the SARS-CoV-2 peak glycoprotein show that, compared to the SARS-CoV peak protein, the affinity for ACE2 is increased by 10 to 20 times. This can be explained by the fact that although the structure is similar, the two peak glycoproteins are not the same ${ }^{7}$.

Idiopathic facial palsy is called Bell's palsy and studies have shown that facial palsy increased during the COVID-19 pandemic period. There are many reports on the relationship between COVID-19 and facial palsy, but little real evidence of its relationship. The exact mechanism of Bell's palsy is unclear. Many different theories, including viral infection, inflammation, ischemia and immunological disorders, have been considered in the etiopathogenesis ${ }^{8-11}$.

SARS-CoV-2 IgM can be detected in blood samples from patients with COVID-19 five days after the onset of 
symptoms, lasts 1 month and then gradually decreases. The average duration of detection of the SARS-CoV-2 IgG antibody is 14 days. It is suggested that SARS-CoV-2 IgM and IgG was useful for the diagnosis of COVID-19 after the corresponding window periods ${ }^{12,13}$. Although Bell's palsy is, by definition, an idiopathic disease, growing evidence shows that several viral infections are related to it. Most studies have shown that Bell's palsy is related to the immune response after a viral infection and usually occurs 1 to 2 weeks after a viral infection. Bell's palsy is believed to result from compression of the seventh cranial nerve in the geniculate ganglion due to significant inflammation of the nerve. The first portion of the facial canal, the labyrinthine segment, is the narrowest and this is where most cases of compression occur. Due to the narrow opening of the facial canal, inflammation causes nerve compression and ischemia ${ }^{14,15}$.

The results of related studies indicated that the SARSCoV-2 IgG + IgM test was positive in $24.3 \%$ of patients with Bell's palsy. In addition, these patients had no history of any symptoms of COVID-19 such as fever, cough, sore throat or shortness of breath in their personal history. This demonstrates a superiority in relation to seroprevalence studies carried out in asymptomatic individuals ${ }^{16}$. Neural ischemia, autoimmune diseases and viral inflammation of facial nerve palsy are considered responsible, but the etiology is unclear ${ }^{17}$. 
Studies on the increase in acute peripheral facial palsy during the COVID-19 pandemic have been published. Direct viral neurophysics or an immune mechanism secondary to elevated pro-inflammatory cytokines can cause facial palsy in COVID-19 18 -23.

Asymptomatic individuals from the randomly selected sample participated in a Spanish study investigating COVID$19 \mathrm{IgG}$ and/or IgM and the prevalence found was $5.47 \% 24$. The seroprevalence of the SARS-CoV-2 IgG and/or IgM antibody in asymptomatic individuals was $2.39 \%$ in Wuhan ${ }^{25}$. The highest prevalence of antibodies against SARS-CoV-2 in the literature was found in asymptomatic people in Sergipe, Brazil. SARS-CoV-2 IgG was found to be $8.3 \%$ and $11.9 \%$ for $\operatorname{IgM}^{26}$.

In another study, it was found that facial palsy may be the only symptom of COVID-19, but they emphasize that further studies with larger groups of patients should be done. The PCR test on patients' first admission could be done to clarify the etiology. The SARS-CoV-2 antibody test to measure IgG and IgM separately can also be performed ${ }^{16}$.

In addition to Bell's palsy, other immune disorders of the nervous system have also been proposed as associated with COVID-19. The involvement of cranial nerves has been described in the context of Guillain-Barré ${ }^{27}$ syndrome and its variants ${ }^{28-30}$. Descriptions of isolated cranial nerve involvement in the context of COVID-19 are scarce ${ }^{19}$.

In an Italian cohort, Guillain-Barré syndrome was reported in approximately $0.5 \%$ of patients with COVID-19, 
with the first symptoms of flaccid paralysis and facial diplegia occurring within 5-10 days after the onset of acute respiratory symptoms ${ }^{31}$.

In China, a 65-year-old woman was admitted to the hospital for a left facial fall preceded by a 2-day history of pain in the mastoid region. There were no fever, cough or previous respiratory symptoms. The physical examination showed palsy of the facial nerve of the left lower motor neuron. The MRI brain showed no abnormalities. However, an RT-PCR throat smear tested positive for the SARS-CoV-2 and chest CT revealed frosted glass shadows in the lower right lung. Left facial palsy was relieved after antiviral treatment with umifenovir and ribavirin ${ }^{32}$.

Facial nerve palsy can be associated with infections, most commonly HSV, as well as VZV and HIV, Lyme disease and Mycobacterium tuberculosis. Non-infectious causes include sarcoidosis and neoplasms. The exact pathogenesis of acute facial nerve palsy remains unclear, but in association with neurotropic herpesvirus (HSV and VZV), it is believed to be related to axonal dissemination and viral replication leading to inflammation and demyelination ${ }^{33}$. In the case of COVID-19, the putative mechanisms of the wide range of neurological manifestations are still unclear ${ }^{34}$.

Coronaviruses are known to have a neuroinvasive propensity. Animal models show that coronavirus of severe acute respiratory syndrome and coronavirus of respiratory syndrome in the Middle East can have a transcriptional route to the brain, causing manifestations in the CNS, as 
previously stated ${ }^{35}$. The mechanism underlying the neurological symptoms in COVID-19 has yet to be clearly elucidated. Similar to patients with Miller Fisher syndrome and cranial perineuritis described in Spain and those with Guillain-Barré syndrome described in Italy, another study reported that the patient studied developed facial palsy isolated from the facial nerve during the initial phase of his disease, in day $6^{28,31}$. This may suggest a parainfectious phenomenon. Serum immunoglobulin G GD1b antibodies were also detected in the patient with Miller Fisher syndrome. In all of these cases with Guillain-Barré syndrome and Miller Fisher syndrome, SARS-CoV-2 was not detected in the CSF. Thus, cranial neuropathies may be related to injuries mediated by pro-inflammatory cytokines, instead of direct viral neutrophism ${ }^{28}$.

Viral dynamics studies show that viral loads are greater 1-2 days before the onset of symptoms and decrease in a monotonic pattern with prolonged viral spread hovering near the level of detection, resulting in RT-PCR results that fluctuate between positive and negative ${ }^{36}$.

Currently, no direct cause and effect has been attributed to neurological deterioration in patients with SARS-CoV-2 and this relationship could be explained in such a plausible way by the association with other failures of the multiple organ system ${ }^{37}$. It has been proposed that SARSCoV-2, like other viruses, such as avian influenza and SARSCoV, can infiltrate the brainstem of mammals through transsynaptic transfer, which can lead to dysfunction in the 
cardiorespiratory centers of the brain stem ${ }^{6}$. Therefore, it has been suggested that the infiltration of SARS-CoV-2 in the CNS may explain the deterioration in the respiratory effort of some patients and their subsequent need for ventilation. Consequently, serial and close neurological observations as a complement to routine serial observations can be an early warning marker of imminent deterioration ${ }^{37}$.

One aspect of SARS-CoV-2, not yet fully understood, is the long-term sequelae that the virus can have on different systems of the body ${ }^{38-41}$. Detailed documentation and longterm follow-up of patients recovered with SARS-CoV-2 will allow conclusions to be drawn in this area. The mechanism underlying the SARS-CoV-2 neuroenvolvement has not yet been fully understood and remains an area of interest. Identifying the modes of transmission is essential to possibly reduce the spread and establish new therapies to target the virus.

\section{CONCLUSION}

Although it is possible to assert, through scientific evidence, that direct viral neurophysics or an immunological mechanism secondary to elevated pro-inflammatory cytokines can cause facial palsy in COVID-19, it is still necessary to understand the pathogenesis of COVID-19 behind the facial palsy, not yet fully understood. It is known that SARS-CoV can infiltrate the brainstem of mammals through trans-synaptic transfer, which can lead to dysfunction of the cardiorespiratory centers of the 
brainstem. It is enough to know whether the same occurs with SARS-CoV-2 in the ganglia that emit motor nerve fibers from the facial nerve. We believe that more research needs to be done to clarify the association, correlation or causality between COVID-19 and neuroimmune diseases.

\section{REFERENCES}

1.Rothan HA, Byrareddy SN. The epidemiology and pathogenesis of coronavirus disease

Autoimmun 2020;109:102433.

(COVID-19) outbreak. J

https://doi.org/10.1016/j.jaut.2020.102433

2. Mao $L$, Jin $H$, Wang $M, H u ~ Y$, Chen $S, H e ~ Q$, et al. Neurologic manifestations of hospitalized patients with coronavirus disease 2019 in Wuhan, China. JAMA Neurol 2020;77:683.

https://doi.org/10.1001/jamaneurol.2020.1127

3. McCray PB, Pewe L, Wohlford-Lenane C, Hickey M, Manzel L, Shi L, et al. Lethal infection of K18-hACE2 mice infected with severe acute respiratory syndrome coronavirus. J Virol 2007;81:813-21. https://doi.org/10.1128/JVI.02012-06

4.Li K, Wohlford-Lenane C, Perlman S, Zhao J, Jewell AK, Reznikov LR, et al. Middle east respiratory syndrome coronavirus causes multiple organ damage and lethal disease in mice transgenic for human dipeptidyl peptidase 4. J Infect Dis 2016;212:712-22. https://doi.org/10.1093/infdis/jiv499

5. Netland J, Meyerholz DK, Moore S, Cassell M, Perlman S. Severe acute respiratory syndrome coronavirus infection causes neuronal death in the absence of encephalitis in mice transgenic for human ACE2. J Virol 2008;82:7264-75. https://doi.org/10.1128/JVI.00737$\underline{08}$

6.Baig A, Khaleeq A, Ali U, Syeda H. Evidence of the COVID-19 virus targeting the CNS: tissue distribution, host-virus interaction, and proposed neurotropic mechanisms. ACS Chem Neurosci 2020;11:9958. https://dx.doi.org/10.1021/acschemneuro.0c00122

7.Wrapp D, Wang N, Corbett K, Goldsmith JA, Hsieh C-L, Abiona O, et al. Cryo-EM structure of the 2019-nCoV spike in the prefusion conformation. Science 2020;367:1260-3.

https://doi.org/10.1126/science.abb2507

8. Peitersen E. Bell's palsy: the spontaneous course of 2,500 peripheral facial nerve palsies of different etiologies Acta Otolaryngol Suppl 2002;122:4-30. https://doi.org/10.1080/000164802760370736

9. McGovern FH, Estevez J, Jackson R. Immunological concept for Bell's palsy: further experimental study. Ann Otol Rhinol Laryngol 1977;86:300-5. https://doi.org/10.1177\%2F000348947708600304 10. McCormick DP. Herpes-simplex virus as a cause of Bell's palsy. 
Lancet

6736(72)91499-7

https://doi.org/10.1016/S0140-

11.Kum RO, Yurtsever Kum N, Ozcan M, Yilmaz YF, Gungor V, Unal $A$, et al. Elevated neutrophil-to-lymphocyte ratio in Bell's palsy and its correlation with facial nerve enhancement on MRI. Otolaryngol Head Neck Surg 2015;152:130-5.

https://doi.org/10.1177/0194599814555841

12.Guo L, Ren L, Yang S, Xiao M, Chang D, Yang F, et al. Profiling early humoral response to diagnose novel coronavirus disease (COVID-19). Clin Infect Dis 2020;71:778-85. https://doi.org/10.1093/cid/ciaa310 13.Zhang G, Nie S, Zhang Z, Zhang Z. Longitudinal change of SARSCov2 antibodies in patients with COVID-19. J Infect Dis 2020;10. https://doi.org/10.1093/infdis/jiaa229

14. Heckmann JG, Urban PP, Pitz S, Guntinas-Lichius O, Gágyor I. The Diagnosis and Treatment of Idiopathic Facial Paresis (Bell's Palsy). Dtsch Arztebl Int 2019;116:692-702.

https://dx.doi.org/10.3238\%2Farztebl.2019.0692

15.Sadé J. Pathology of Bell's Palsy. Arch Otolaryngol 1972;95:406-14. https://doi.org/10.1001/archotol.1972.00770080642003

16. Islamoglu Y, Celik B, Kiris M. Facial paralysis as the only symptom of COVID-19: A prospective study. Am J Otolaryngol 2021;42:102956. https://doi.org/10.1016/j.amjoto.2021.102956

17. May M, Klein SR. Differential diagnosis of facial nerve palsy Otolaryngol Clin North Am 1991;24:613-45.

https://doi.org/10.1016/S0030-6665(20)31118-X

18.Casas E, Barbosa A, Rubio-García E, Cebrián J, Díaz-Pérez C, de la Fuente $\mathrm{E}$, et al. Parálisis facial periférica aislada en un paciente con COVID-19 [Isolated peripheral facial paralysis in a patient with COVID19]. Rev Neurol 2020;71:40-1.

https://doi.org/10.33588/rn.7101.2020229

19.Goh Y, Beh DLL, Makmur A, Somani J, Chan ACY. Pearls \& oysters: facial nerve palsy in COVID-19 infection. Neurology 2020;95:364-7.

https://doi.org/10.1212/WNL.0000000000009863

20. Ribeiro BNF, Marchiori E. Facial palsy as a neurological complication of SARS-CoV-2. Arq Neuropsiquiatr 2020;78:667.

https://doi.org/10.1590/0004-282X20200127

21.Codeluppi L, Venturelli F, Rossi J, Fasano A, Toschi G, Pacillo F, et al. Facial palsy during the COVID-19 pandemic. Brain Behav 2020; e01939. https://doi.org/10.1002/brb3.1939

22.Zammit M, Markey A, Webb C. A rise in facial nerve palsies during the coronavirus disease 2019 pandemic. J Laryngol Otol 2020;14. https://doi.org/10.1017/S0022215120002121

23. Brisca G, Garbarino F, Carta S, Palmieri A, Vandone M, Severino $M$, et al. Increased childhood peripheral facial palsy in the emergency department during COVID-19 pandemic. Pediatr Emerg Care 2020;36:e595-6. https://doi.org/10.1097/PEC.0000000000002231

24. Montenegro P, Brotons C, Serrano J, Fernández D, Garcia-Ramos C, Ichazo B, et al. Community seroprevalence of COVID-19 in probable and possible cases at primary health care centres in Spain. Fam Pract 
2020; cmaa096. https://doi.org/10.1093/fampra/cmaa096

25.Pan Y, Li X, Yang G, Fan J, Tang Y, Hong X, et al. Seroprevalence of SARS-CoV-2 immunoglobulin antibodies in Wuhan, China: part of the city-wide massive testing campaign. Clin Microbiol Infect 2020;33035672. https://doi.org/10.1016/j.cmi.2020.09.044

26.Borges LP, Martins AF, de Melo MS, de Oliveira MGB, Neto JMR, Dósea MB, et al. Seroprevalence of SARS-CoV-2 IgM and IgG antibodies in an asymptomatic population in Sergipe, Brazil. Rev Panam Salud Publica 2020;44.

https://doi.org/10.26633/RPSP.2020.108

27.Lascano AM, Epiney J-B, Coen M, Serratrice J, Bernard-Valnet $R$, Lalive $\mathrm{PH}$, et al. SARS-CoV-2 and Guillain-Barré syndrome: AIDP variant with favorable outcome. Eur J Neurol 2020;27:1751-3. https://doi.org/10.1111/ene.14368

28.Gutiérrez-Ortiz C, Méndez A, Rodrigo-Rey S, San Pedro-Murillo E, Bermejo-Guerrero L, Gordo-Mañas R, et al. Miller Fisher syndrome and polyneuritis cranialis in COVID-19. Neurology 2020;95:e601-5. https://doi.org/10.1212/WNL.0000000000009619

29. Caamaño DSJ, Beato RA. Facial diplegia, a possible atypical variant of Guillain-Barré syndrome as a rare neurological complication of SARS-CoV-2. J Clin Neurosci 2020;77:230-2.

https://doi.org/10.1016/j.jocn.2020.05.016

30.Defreitasferreira ACA, Romão TT, Silvamacedo Y, Pupe C, Nascimento OJ. COVID-19 and herpes zoster co-infection presenting with trigeminal neuropathy. Eur J Neurol 2020;27:1748-50. https://doi.org/10.1111/ene.14361

31.Toscano G, Palmerini F, Ravaglia S, Ruiz L, Invernizzi $P$, Cuzzoni MG, et al. Guillain-Barré syndrome associated with SARS-CoV-2. N Engl J Med Epub 2020;382:2574-6.

https://doi.org/10.1056/NEJMc2009191

32. Yue Wan, Shugang Cao, Qi Fang et al. Coronavirus disease 2019 complicated with Bell's palsy: a case report. Version 1. Res Squ 2020;3.rs-23216/v1. https://doi.org/10.21203/rs.3.rs-23216/v1

33. Eviston TJ, Croxson GR, Kennedy PGE, Hadlock T, Krishnan VA. Bell's palsy: aetiology, clinical features and multidisciplinary care. J Neurol Neurosurg Psychiatry 2015;86:1356-61.

http://dx.doi.org/10.1136/jnnp-2014-309563

34.Romoli M, Jelcic I, Bernard-Valnet R, García-Azorín D, Mancinelli L, Akhvlediani $T$, et al. A systematic review of neurological manifestations of SARS-CoV-2 infection: the devil is hidden in the details. Eur J Neurol 2020;27:1712-26. https://doi.org/10.1111/ene.14382

35. Li YC, Bai WZ, Hashikawa T. The neuroinvasive potential of SARSCoV2 may play a role in the respiratory failure of COVID-19 patients. J Med Virol 2020;92:552-5. https://doi.org/10.1002/jmv.25728

36. He X, Lau EHY, Wu P, Deng X, Wang J, Hao X, et al. Temporal dynamics in viral shedding and transmissibility of COVID-19. Nat Med 2020;26:672-5. https://doi.org/10.1038/s41591-020-0869-5

37. Whittaker A, Anson M, Harky A. Neurological manifestations of COVID-19: a systematic review and current update. Acta Neurol Scand 
2020;142:14-22. https://doi.org/10.1111/ane.13266

38.Kermali M, Khalsa RK, Pillai K, Ismail Z, Harky A. The role of biomarkers in diagnosis of COVID-19 - A systematic review. Life Sci 2020;117788. https://doi.org/10.1016/j.Ifs.2020.117788

39.Zaim S, Chong JH, Sankaranarayanan V, Harky A. COVID-19 and Multi-Organ Response. Curr Probl Cardiol 2020;100618.

https://doi.org/10.1016/j.cpcardiol.2020.100618.

40.Khan IH, Zahra SA, Zaim S. At the heart of COVID-19. J Card Surg 2020;35:1287-94. https://doi.org/10.1111/jocs.14596.

41. Harky A, Chiu CM, Yau THL, Lai SHD. Cancer Patient Care during COVID-19. Cancer Cell 2020;37:749-50.

https://doi.org/10.1016/j.ccell.2020.05.006 